\title{
Energy and Carbon Intensity: A Study on the Cross- Country Industrial Shift from China to India and SE Asia.
}

\author{
Dimitrios Pappas ${ }^{\mathrm{a}}$, Konstantinos J. Chalvatzis ${ }^{\mathrm{a}}$, Dabo Guan ${ }^{\mathrm{b}}$, Alexis Ioannides ${ }^{\mathrm{a}}$ \\ ${ }^{a}$ Norwich Business School, University of East Anglia, Norwich NR4 7TJ, United Kingdom \\ ${ }^{b}$ School of International Development, University of East Anglia, Norwich NR4 7TJ, United Kingdom \\ ${ }^{a, b}$ Tyndall Centre for Climate Change Research, University of East Anglia, Norwich NR4 7TJ, United Kingdom
}

\section{Highlights}

- Emissions intensity higher in India and SE Asia countries compared to China.

- India's emissions intensity triple that of China in non-metallic minerals industry.

- India's emissions intensity double that of China in iron and steel industry.

- Indonesia's emissions intensity double that of China in non-metallic minerals sector.

- Paris Agreement INDC commitments to be challenged by industrial relocation.

\begin{abstract}
$^{1}$
The potential relocation of various industrial sectors from China to India and countries of the SE Asian region presents low cost opportunities for manufacturers, but also risks rising for energy demand and $\mathrm{CO}_{2}$ emissions. A cross-country shift of industrial output would present challenges for controlling emissions since India and SE Asian countries present higher industrial emissions intensity than China. We find that although there is a convergence in emissions intensity in the machinery manufacturing and paper and pulp industries, there are significant variations in all other industrial sectors. Indian emissions intensity is double that of China in the iron and steel and textile and leather industries and almost triple in the cement industry; Indonesian emissions intensity is almost double that of China in the non-metallic minerals and textile and leather industries and 50\% higher in the chemical and petrochemical industry. We demonstrate that the expected higher emissions are driven by both a higher carbon fuel mix intensity in the recipient countries ${ }^{1}$ and higher energy intensity in their industrial activities. While industrial relocation could benefit certain countries financially, it would impose considerable threats to their energy supply security and capacity to comply with their Paris Agreement commitments.
\end{abstract}

Keywords: India; China; SA Asia; Industrial emissions; Energy intensity; Carbon intensity

Corresponding author. Tel: +44 (0) 1603597241;

E-mail address: k.chalvatzis@uea.ac.uk

${ }^{1}$ The short version of the paper was presented at ICAE2017, Aug 21-24, Cardiff, UK. This paper is a substantial extension of the short version of the conference paper 


\section{Introduction}

While China has been firmly established as the main locomotive of the global economy, it is also identified as a global industrial production hub. However, China shows evidence of slowing down with its economic growth rate being in decline, from $6.7 \%$ to $6.2 \%$ between 2016 and 2018 [1]. At the same time, Indonesia, the Philippines and Thailand are experiencing a $5.1 \%, 6.7 \%$ and $3.2 \%$ growth rate respectively for 2017 [1-4]. India's GDP growth stood at $6.7 \%$ in 2017 and is expected to accelerate to $7.4 \%$ and $7.8 \%$ in 2018 and 2019 respectively $[5,6]$.

Overseas firms focus on India, among others, for establishing their production lines, with India surpassing China for greenfield FDI by $\$ 6.4$ billion in 2015 [7,8] aided by initiatives such as the "Make in India" programme aimed in attracting foreign investors. In contrast to the anaemic growth of crisis hit countries in the EU [9] and other regions, SE Asia provides promising industrial hub destinations. Apart from India [10], Thailand, the Philippines and Indonesia are discussed as potential destinations by industries wanting to relocate from China $[11,12]$. In that context and in comparison to China, India, Indonesia, the Philippines and Thailand present young demographic characteristics which enhance their potential as destination for manufacturers [13,14]. However, they also present different energy and emission inventories [15]. From a manufacturer's point of view, industrial relocation from China to SE Asian countries can be preferable for a range of factors such as ageing population and the respective increased social security costs [16], increased labour and production costs [17], higher environmental regulation standards [18], higher land value and less attractive tax policies $[19,20]$.

Cross-country shift of industrial output presents different scales of production challenges that generate further impacts. The increase in production costs can be the result of increased energy input, defined by energy intensity; the ratio of energy consumption per economic output [21]. With the Chinese emissions taking the lead globally from 2005 onwards [22], carbon emissions are mainly driven by economic growth and energy consumption. Indeed, focusing on the case of China, India, Indonesia, the Philippines and Thailand, economic growth is strongly linked to increased energy consumption [23]. Empirical evidence shows that a unidirectional causality exists, running from economic growth to energy consumption [24]. This causality has also been found to be valid in the case of the Philippines and Thailand, from gross fixed capital formation to energy consumption [25]. 
Industrial production in the countries studied follows a growing trajectory with India's output rising by $60 \%$ from 2000 to 2012 [26]. Improving energy and carbon intensity acts as a basic element of sustainable development for mitigating the pressure posed by increased energy demand and environmental policies against climate change. Energy intensity improvements aid industrial sector competitiveness due to decreased energy costs and exposure to energy price volatility. On an economy-wide scale, effects on trade-balance can be observed not only in imported energy resources but on energy resources which are produced domestically. This is due to increased energy resources being available for export, with the potential of achieving high prices in international markets [27].

India's energy intensity of various industrial sectors; including cement, iron \& steel, paper pulp \& print, has been evaluated for the period of 1973-1994 [28] using a "base-year" methodology. Voigt et al. [29] used the World Input Output Database (WIOD) to analyse energy intensity trends of 40 major economies, including China, India and Indonesia for 19952007. They attributed China's energy intensity reduction to efficiency improvements. India was classified as the only country of the sample that initially presented high energy intensity and slow energy intensity reduction. This study highlighted a shift of the global economy gross output from countries with low energy intensity; eg. US, Japan, to countries with higher energy intensity such as China and to India in a lesser extent during that timeframe. Sadorsky [30] used a compiled model of heterogeneous panel regression techniques to measure the effect of industrialization and urbanization on energy intensity in developing countries such as China, India, the Philippines, Thailand and Indonesia and concluded that policies aimed at speeding up industrialization will increase energy intensity, only to be countered by income growth offsetting the impact of the former.

Energy intensity measures energy consumption per economic output and the examined countries have progressed differently in developing the examined industrial sectors [31]. This should lead to use of different technologies, with different attributes in relation to energy consumption to produce the specific industrial goods [32]. We therefore, hypothesize that even when looking at the same industrial sector, countries will have different energy intensity per economic output (H1). Energy intensity relies largely on the technologies used and gradually cross-country knowledge transfer progresses by either governmental schemes or multinationals active in several countries [33]. Therefore, we hypothesize that different countries' energy intensity for the same industrial sectors will converge over time $(\mathrm{H} 2)$.

When estimating carbon intensity, the specific fuel mix of every industrial sector is important as every fuel has significantly different emission factors [34]. This impact is different 
when carbon intensity is estimated per energy used and per economic output $[35,36]$. As a result, we hypothesize that different countries will present significantly different carbon intensity patterns, even for the same industry, when carbon intensity is estimated as a function of energy used and economic output (H3). Moreover, while technological convergence can be expected, fuel mix convergence might be significantly more difficult to achieve as countries prioritise their indigenous fuel reserves. Therefore, we hypothesize that different countries' carbon intensity per energy used will not converge in a short time (H4).

The IEA has directly linked lower energy intensity to emission reduction; in extension to carbon intensity, and increased energy security [37,38]. However, countries differ from one another in energy and carbon intensity levels, presenting research interest for evaluating their performance, enabling further appraisal of their potential for intensity levels reduction. Calculating sectoral energy and carbon intensity is a first necessary step in locating the country needs not only for technological progress but also output structure, technical efficiency, capital and labour energy ratio as these factors act as energy intensity drivers [39]. The relocation's impact on industrial $\mathrm{CO}_{2}$ emissions is complex to estimate and depends on the specific country shifts, their relative energy intensity and their relative emissions intensity.

While the extent and trajectory of industrial relocation between the aforementioned countries is an issue for debate in the literature [40,41], in this manuscript, we compare the energy and emissions intensity of China, India and selected SE Asian countries to better understand the required energy for producing the same industrial output and the $\mathrm{CO}_{2}$ impacts of a potential industrial relocation. We look into a range of industrial sectors to capture their intricacies in the examined countries. Therefore, this work provides a methodological contribution in reconciling energy, emissions and financial output datasets from the IEA and UNIDO. Furthermore, our results improve the understanding of the impact that potential relocations of industries have in terms of emissions, and more significantly to identify which sectors might be best and worst placed to accommodate relocation activities in the near future. Therefore, we advance the existing research by clarifying the methods and providing the results for country and industrial sector specific hierarchies in energy and carbon intensity.

After this brief introduction, this manuscript continues with an extensive explanation of the methodological approach and the use of specific datasets in Section 2. In Section 3, we present the results for all the examined countries and industrial sectors. Discussion of the results continues in Section 4 and we provide concluding remarks in Section 5.

\section{Method and Data}




\subsection{Data}

According to the United Nations Sustainable Development Division (UNSDD), energy intensity is defined as the ratio of energy use to GDP [42] and as the final energy consumption divided by the Gross Value Added (GVA) at constant prices [43]. While Eurostat defines the unit of economic output as the GVA, the UNSDD argues that a standardized methodology for calculating energy intensity does not exist [44]. This claim is evidently supported by the US Office of Energy Efficiency \& Renewable Energy, which plainly expresses the energy intensity as energy per unit of output [45]. For the purposes of this research, the industrial output that will be extracted from the appropriate database is expressed as the total output in current million US dollars. The IEA database is used for extracting energy consumption data per fuel product and industrial flows [46] and presents a wide range of flows and time series data [47]. IEA data has been used extensively for research on China [48,49], Indonesia [50,51], the Philippines and Thailand [52]. For comparison, regional data provided by Indian authorities (MOSPI) is characterized by limited length of time-series, generic fuel products and inconsistent data provision [53].

Table 1. Breakdown of products used as input per industrial sector of India, China, Indonesia, the Philippines and Thailand. Data Source: [54]

\begin{tabular}{|c|c|c|c|c|c|c|c|c|c|c|c|c|c|c|c|c|c|c|c|c|c|c|c|c|c|}
\hline$\tau$ & $\begin{array}{l}\text { Industrial } \\
\text { Sectors }\end{array}$ & 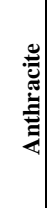 & $\stackrel{0}{0}$ & 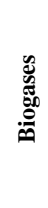 & 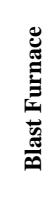 & 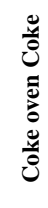 & 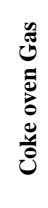 & 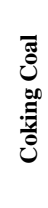 & $\frac{\overline{0}}{\bar{g}}$ & 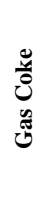 & 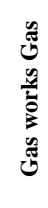 & 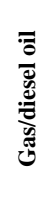 & 苟 & ڤِ & 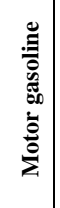 & 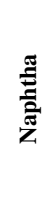 & 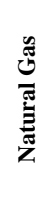 & 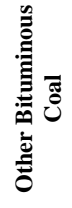 & 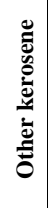 & 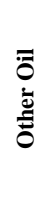 & 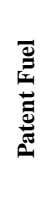 & 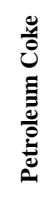 & 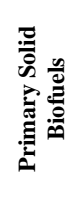 & 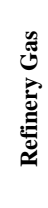 & 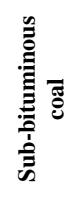 \\
\hline \multirow{12}{*}{ שֶّ } & Chem. & & & & & & & $\sqrt{ }$ & $\sqrt{ }$ & & & $\sqrt{ }$ & $\sqrt{ }$ & $\sqrt{ }$ & & & & $\sqrt{ }$ & & & & & & & \\
\hline & $I \& S$ & & & & $\sqrt{ }$ & $\sqrt{ }$ & $\sqrt{ }$ & $\sqrt{ }$ & $\sqrt{ }$ & & $\sqrt{ }$ & $\sqrt{ }$ & $\sqrt{ }$ & $\sqrt{ }$ & & & & $\sqrt{ }$ & & & & & & & \\
\hline & Mach. & & & & & & & & $\sqrt{ }$ & & & $\sqrt{ }$ & & $\sqrt{ }$ & & & & & & & & & & & \\
\hline & N.M.M. & & & & & & & $\sqrt{ }$ & $\sqrt{ }$ & & & $\sqrt{ }$ & $\sqrt{ }$ & & & & & $\sqrt{ }$ & & & & $\sqrt{ }$ & & & \\
\hline & PPP. & & & & & & & $\sqrt{ }$ & & & & & $\sqrt{ }$ & & & & & $\sqrt{ }$ & & & & & & & \\
\hline & T\&L & & & & & & & & $\sqrt{ }$ & & & $\sqrt{ }$ & $\sqrt{ }$ & $\sqrt{ }$ & & & & $\sqrt{ }$ & & & & & & & \\
\hline & Chem. & & & & & & & & $\sqrt{ }$ & & $\sqrt{ }$ & $\sqrt{ }$ & & $\sqrt{ }$ & & & $\sqrt{ }$ & $\sqrt{ }$ & $\sqrt{ }$ & & $\sqrt{ }$ & & & $\sqrt{ }$ & \\
\hline & I\&S & & & & & & & & $\sqrt{ }$ & $\sqrt{ }$ & & $\sqrt{ }$ & & $\sqrt{ }$ & & & $\sqrt{ }$ & $\sqrt{ }$ & $\sqrt{ }$ & & & & & & \\
\hline & Mach. & & & & & & & & $\sqrt{ }$ & $\sqrt{ }$ & & $\sqrt{ }$ & & $\sqrt{ }$ & & & $\sqrt{ }$ & $\sqrt{ }$ & $\sqrt{ }$ & & & & & & \\
\hline & N.M.M. & & & & & & & & $\sqrt{ }$ & $\sqrt{ }$ & & $\sqrt{ }$ & & $\sqrt{ }$ & & & $\sqrt{ }$ & $\sqrt{ }$ & $\sqrt{ }$ & & & & & & $\sqrt{ }$ \\
\hline & PPP. & & & & & & & & $\sqrt{ }$ & & $\sqrt{ }$ & & & $\sqrt{ }$ & & & $\sqrt{ }$ & $\sqrt{ }$ & $\sqrt{ }$ & & & & & & $\sqrt{ }$ \\
\hline & $\mathrm{T} \& \mathrm{~L}$ & & & & & & & & $\sqrt{ }$ & & $\sqrt{ }$ & $\sqrt{ }$ & & $\sqrt{ }$ & & & $\sqrt{ }$ & $\sqrt{ }$ & $\sqrt{ }$ & & & & & & \\
\hline \multirow{6}{*}{ 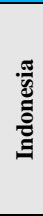 } & Chem. & & & & & & & & $\sqrt{ }$ & & & $\sqrt{ }$ & & & & & $\sqrt{ }$ & $\sqrt{ }$ & $\sqrt{ }$ & & & & & & $\sqrt{ }$ \\
\hline & $I \& S$ & $\sqrt{ }$ & & & $\sqrt{ }$ & $\sqrt{ }$ & & $\sqrt{ }$ & $\sqrt{ }$ & & & $\sqrt{ }$ & & & & & $\sqrt{ }$ & $\sqrt{ }$ & & & & & & & $\sqrt{ }$ \\
\hline & Mach. & & & & & & & & & & & $\sqrt{ }$ & & & & & & & & & & & & & \\
\hline & N.M.M. & & & & & & & & $\sqrt{ }$ & & & $\sqrt{ }$ & & & & & $\sqrt{ }$ & & & & & & & & $\sqrt{ }$ \\
\hline & PPP. & & & & & & & & & & & & & & & & & & & & & & & & $\sqrt{ }$ \\
\hline & T\&L & & & & & & & & $\sqrt{ }$ & & & $\sqrt{ }$ & & & & & & & & & & & & & \\
\hline \multirow{6}{*}{ 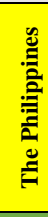 } & Chem. & & & & & & & & $\sqrt{ }$ & & & $\sqrt{ }$ & & $\sqrt{ }$ & & & & & $\sqrt{ }$ & & & & & & \\
\hline & I\&S & & & & $\sqrt{ }$ & $\sqrt{ }$ & & & & & & $\sqrt{ }$ & & $\sqrt{ }$ & & $\sqrt{ }$ & & & $\sqrt{ }$ & & & & & & \\
\hline & Mach. & & & & & & & & $\sqrt{ }$ & & & $\sqrt{ }$ & & $\sqrt{ }$ & & & & & $\sqrt{ }$ & & & & & & \\
\hline & N.M.M. & & & & & & & & $\sqrt{ }$ & & & $\sqrt{ }$ & & $\sqrt{ }$ & & & & & $\sqrt{ }$ & & & & & & \\
\hline & PPP. & & & & & & & & $\sqrt{ }$ & & & $\sqrt{ }$ & & & & & & & $\sqrt{ }$ & & & & & & \\
\hline & T\&L & & & & & & & & $\sqrt{ }$ & & & $\sqrt{ }$ & & $\sqrt{ }$ & & & & & $\sqrt{ }$ & & & & & & \\
\hline \multirow{3}{*}{ 垔 } & Chemical & & & & & & & & $\sqrt{ }$ & & & $\sqrt{ }$ & & $\sqrt{ }$ & $\sqrt{ }$ & & $\sqrt{ }$ & & $\sqrt{ }$ & & & & & & \\
\hline & $I \& S$ & & & & $\sqrt{ }$ & $\sqrt{ }$ & & & $\sqrt{ }$ & & & $\sqrt{ }$ & & $\sqrt{ }$ & & & $\sqrt{ }$ & & $\sqrt{ }$ & & & & & & \\
\hline & Machinery & & & & & & & & $\sqrt{ }$ & & & $\sqrt{ }$ & & $\sqrt{ }$ & $\sqrt{ }$ & & $\sqrt{ }$ & & $\sqrt{ }$ & & & & & & \\
\hline
\end{tabular}




\begin{tabular}{|l|l|l|l|l|l|l|l|l|l|l|l|l|l|l|l|l|l|l|l|l|l|l|l|l|l|}
\hline N.M.M. & & & & & & & & $\sqrt{ }$ & & & $\sqrt{ }$ & $\sqrt{ }$ & $\sqrt{ }$ & $\sqrt{ }$ & & $\sqrt{ }$ & $\sqrt{ }$ & $\sqrt{ }$ & & & & & & \\
\hline PPP. & & & & & & & & $\sqrt{ }$ & & & $\sqrt{ }$ & $\sqrt{ }$ & $\sqrt{ }$ & $\sqrt{ }$ & & $\sqrt{ }$ & & $\sqrt{ }$ & & & & & & \\
\hline & T\&L & & & & & & & & $\sqrt{ }$ & & & $\sqrt{ }$ & $\sqrt{ }$ & $\sqrt{ }$ & & & $\sqrt{ }$ & & & $\sqrt{ }$ & & & & & \\
\hline
\end{tabular}

Focusing on the breakdown of products and flows found in Table 1, the labels are explained as following according to the IEA standards: "Chemical" refers to the chemical and petrochemical; "I\&S" is the iron and steel; "N.M.M." stands for non-metallic minerals; "N-S" as non-specified; "PPP" as the paper pulp and print; and finally, "T\&L" as the textile and leather industries. The physical quantities of products [55] presented above (Table 1) are being multiplied with their respective NCVs as these are found in IEA datasets [47] and organized according to their flows. The formula used is presented below:

$$
E_{i, j, k}=E p h y_{i, j, k} * N C V_{i, j, k}
$$

This does not apply for gases as these are already converted to heat. Where $E$ stands for Energy expressed as Heat in PJ, $\mathrm{E}_{\text {phy }}$ stands for Energy in physical quantity measured in kilotonnes $(\mathrm{kt})$ and NCV stands for the Net Calorific Value $(\mathrm{kj} / \mathrm{kg})$. The indicators stand for $\mathrm{i}$ : year; j: product; and k: flow. Where the flow is not specifically described for the NCV, the generic NCV of the industry, according to the IEA data, is used. The heat sum (E) of the products per flow (industrial sector) expressed as $\mathrm{E} k$ is then calculated. Where $n$ stands as the sum of the products $(j)$ used for each flow $(k)$ as those are specified above (Table 1).

$$
\begin{gathered}
E k=\left(E i_{1980} j_{1}+E i_{1981} j_{1}+\cdots+E i_{2011} j_{1}\right)+\left(E i_{1980} j_{2}+E i_{1981} j_{2}+\cdots+E i_{2011} j_{2}\right) \\
+\left(E i_{1980} j_{n}+E i_{1981} j_{n}+\cdots+E i_{2011} j_{n}\right)
\end{gathered}
$$

Table 2. Sum of categories for converting UNIDO ISIC rev3.0 industrial output in current million dollars to IEA ISIC rev 4.0 classification. Data Source: [56]

\begin{tabular}{l|l}
\hline $\begin{array}{l}\text { IEA classification } \\
\text { (ISIC Category rev } \\
\text { 4.0) }\end{array}$ & $\begin{array}{l}\text { ISIC Category rev 3.0 } \\
\text { sums for conversion } \\
\text { to rev } 4.0\end{array}$ \\
\hline $\begin{array}{l}\text { Chemical and } \\
\text { Petrochemical }\end{array}$ & $23+24$ \\
\hline Iron and Steel & $\begin{array}{l}27 \text { (incl. non-ferrous } \\
\text { metals) }\end{array}$ \\
\hline Machinery & $\mathbf{2 8 + 2 9 + 3 0}$ \\
\hline Non-metallic minerals & $\mathbf{2 6}$ \\
\hline Paper, Pulp and Print & $\mathbf{2 1 + 2 2}$ \\
\hline Textile and Leather & $17+18+19$ \\
\hline
\end{tabular}

Matching the UNIDO and IEA selected data is not straight-forward as it requires harmonisation of different classifications, which are not established in the literature. However, it is an essential step to perform the calculations described in Sections 2.2 and 2.3; therefore, we have put forward a proposal for this conversion (Table 2). For each flow, the respective output in million dollars is being published by the United Nations Industrial Development 
Organization (UNIDO) [56]. The database to be used is INDSTAT2 ISIC rev 3.0 as this is provided by UNIDO [56] and summed up where needed to match the IEA classification (Table 2).

Since the data provided by UNIDO is in current million US\$, they must be converted to constant 2005 US\$ values to perform a timeline analysis. As a result, the output per year in current million US\$ is divided with the index value of the corresponding year with 2005 acting as the base year, as provided by the Bureau of Labor Statistics (BLS) [57]. The conversion formula is as following:

$$
T_{2005 \text { constant US } \$}=\frac{T_{\text {current US } \$}}{\left(C P I_{2005 \text { base index }} / 100\right)}(3)
$$

\subsection{Energy Intensity}

Applied on an annual time series, the formula produces the industrial output in 2005 constant US\$ for 1998-2012. Following the practice of energy intensity being calculated as Joule/US\$ according to international literature [58,59], the following formulas are applied for every flow that sums up the products as already shown.

$$
\begin{gathered}
E(T J)=\frac{E(P J)}{1000000}(\mathbf{4}) \\
\text { Energy Intensity }=\frac{E_{i, j, k}(T J)}{\text { constant } 2005 \text { million US\$ }}
\end{gathered}
$$

For Thailand and the Philippines, median values have been used in yearly gaps where IEA data is not available to present the energy intensity ${ }^{2}$. The schematic process for calculating energy intensity is presented in Figure 3.

${ }^{2}$ Median values for the extraction of energy intensity results are used for the years 2000, 2002, 2004, 2007, 2011 for the Philippines and 1999, 2001 for Thailand. 


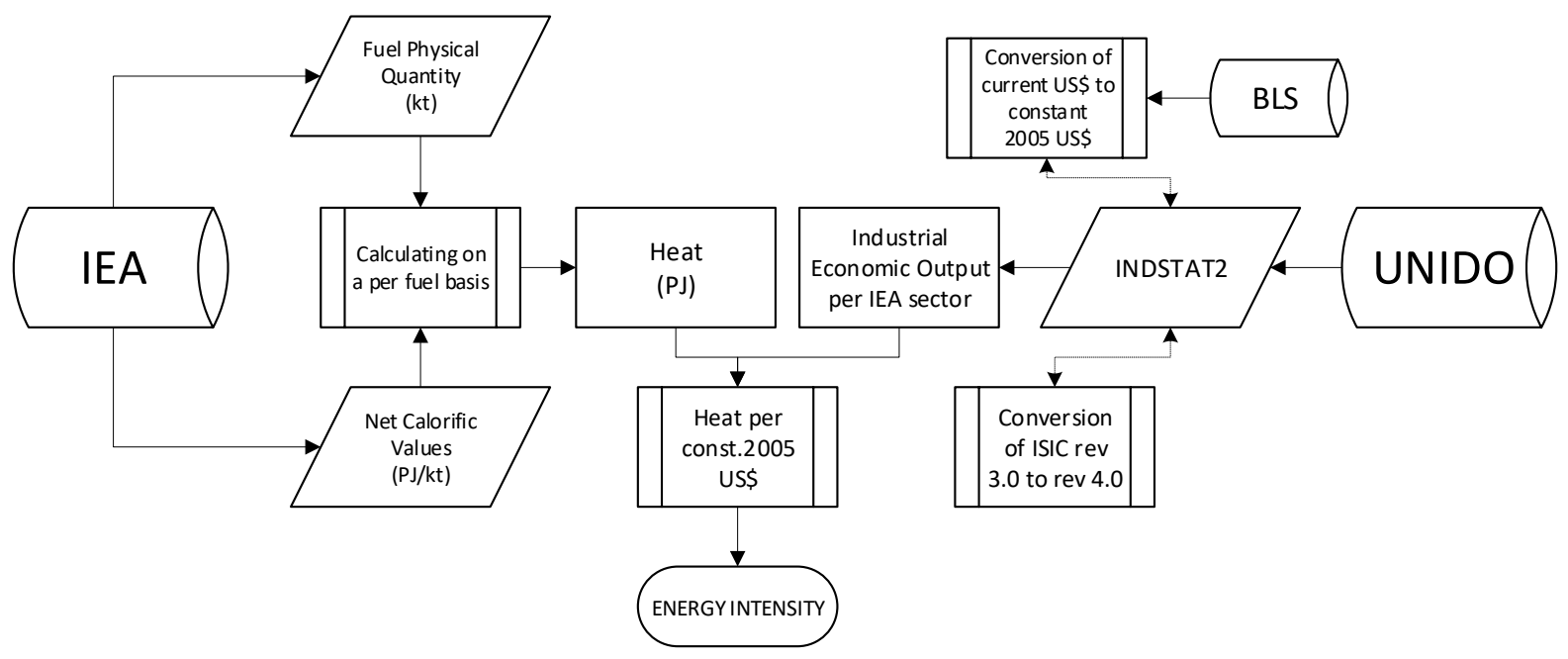

Figure 3. Energy intensity calculation process.

\subsection{Carbon Intensity}

Carbon intensity can be expressed as the emissions of $\mathrm{CO}_{2}$ per total economic output [60] or $\mathrm{CO}_{2}$ emissions per total primary energy supply (TPES) according to the IPCC [61]. To calculate $\mathrm{CO}_{2}$ emissions intensity, the IEA database has been selected as the most appropriate to extract the raw primary energy data of the industrial sectors examined. IEA has a wide variety of flows and respective Net Calorific Values (NCVs) per country, extended time series availability and reporting consistency. The economic total output values have been extracted from UNIDO data and converted to US $2005 \$$ values and ISIC rev.4 to match the reporting methodology of IEA [56]. Physical quantities of fuels are converted to petajoules, and by using the appropriate IPCC net carbon content per fuel [62], are summed for each industrial sector's total $\mathrm{CO}_{2}$ emissions. The breakdown of the products and flows has been conducted where each respective activity can be found and follows that presented in Table 1 .

The equations followed for extracting $\mathrm{CO}_{2}$ intensity data are following the pattern of energy intensity as per (1) and (2)

$$
\mathrm{CO}_{2}(i, j, k)=\text { Carbon content }\left(\frac{k t}{P J}\right) * \text { Carbon oxidization rate } * \text { CtoCO } \mathrm{O}_{2} \text { conversion }(\mathbf{6})
$$

The carbon oxidization rates have been accounted as 0.98 for Coal products, 0.99 for Oil products and 0.995 for Natural Gas. The $\mathrm{C}$ to $\mathrm{CO}_{2}$ conversion rate is accounted as the result of the molar mass of carbon dioxide (44) to the atomic mass of carbon (12) resulting to equation (6) which accounts the mass of total $\mathrm{CO}_{2}$ for all fuel products per industrial sector expressed in kt. To calculate the appropriate carbon intensity, equation (7) is used: 


$$
\text { Carbon Intensity }(C I)=\frac{C O_{2(i, k)}}{E_{(i, k)}}(7)
$$

This equation expresses the carbon intensity (CI) for each year and flow, including all products. The schematic process for calculating carbon intensity per total primary energy supply (TPES) and per economic output are presented in the following Figures $\mathbf{4}$ and $\mathbf{5}$.

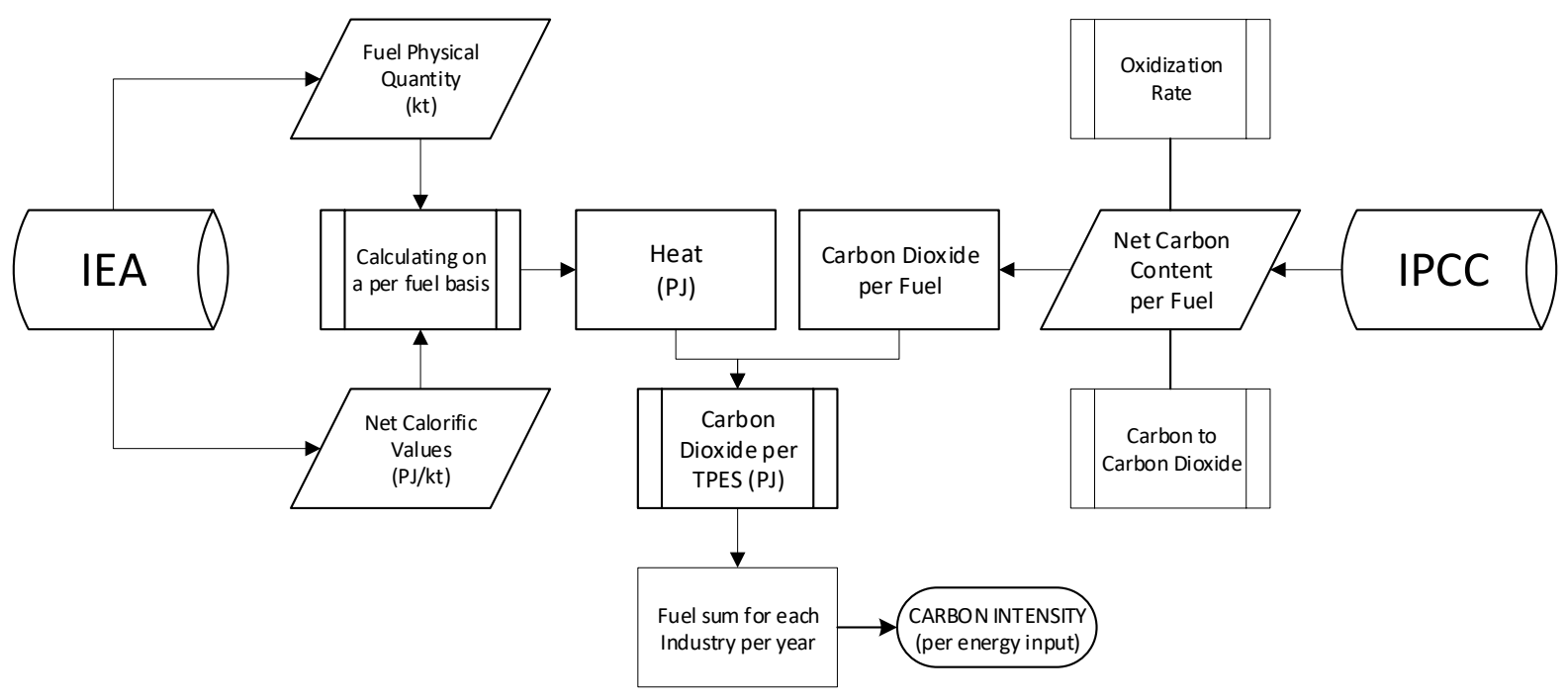

Figure 4. Carbon intensity per TPES calculation process.

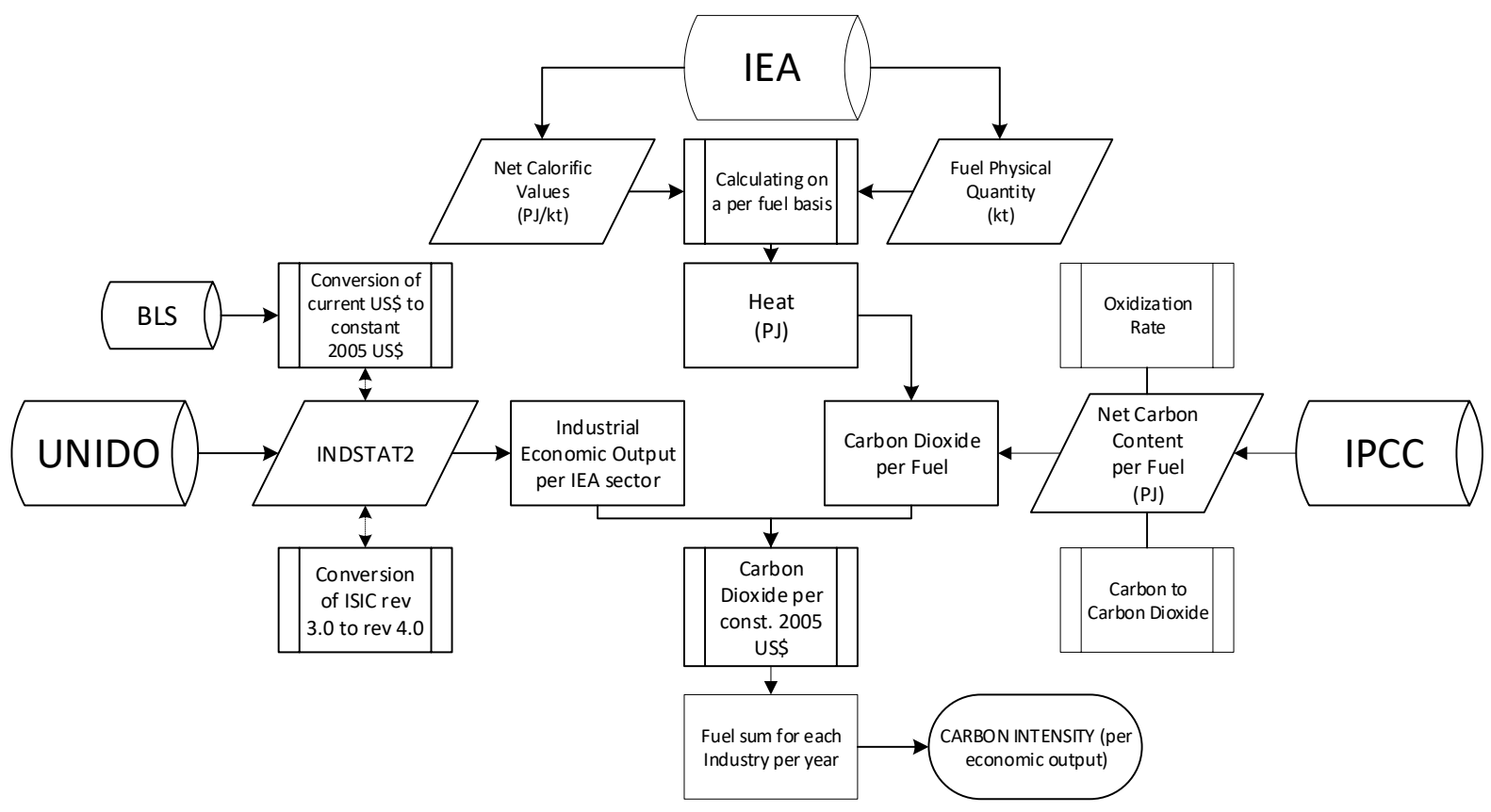

Figure 5. Carbon intensity per economic output calculation process. 


\section{Presentation of the Results}

3.1 Energy intensity

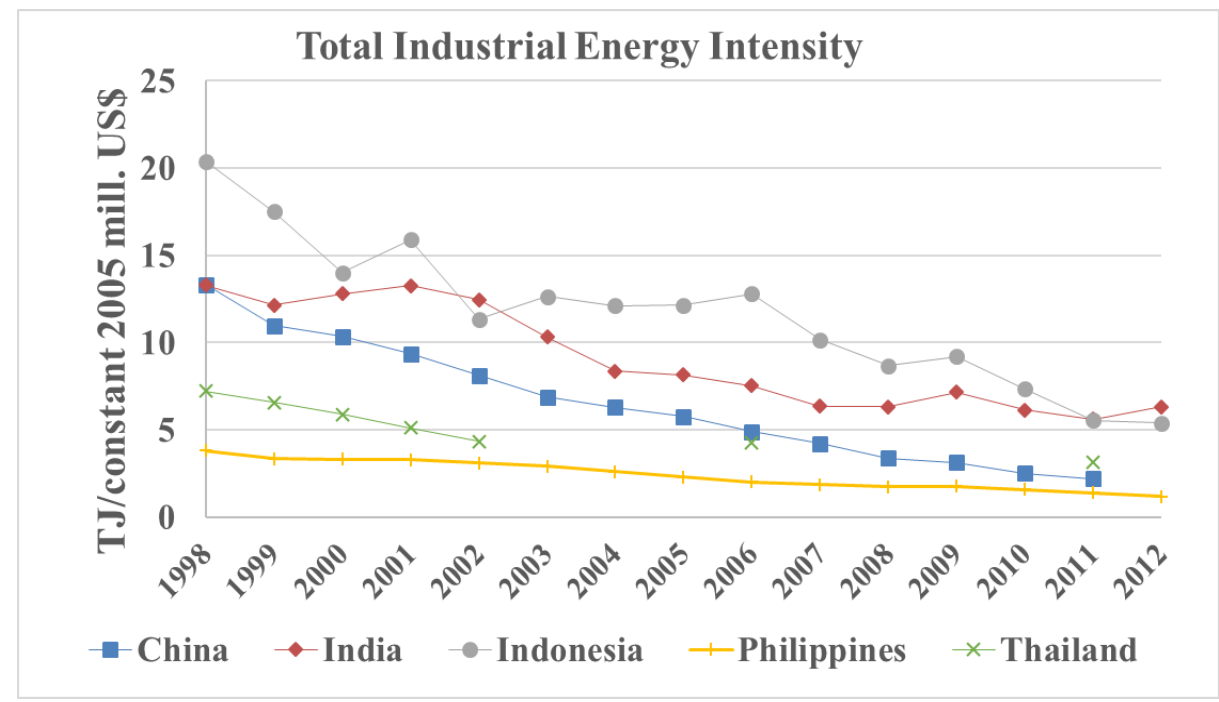

Fig. 6. Total industrial energy intensity timeline of China, India, Indonesia, Philippines and Thailand 19982012. Data Source: $[63,64]$

The overall industrial energy intensity in India is more than double that of China (Figure 4). Specifically, the energy intensity of India has shown a progressively continuous decline except for 2009 and 2012. This declining trend is similar to that of China, which from 1999 onwards has been decreasing. In absolute terms, however, China needs approximately half the energy India needs to produce the same economic output. Despite the different levels of energy intensity in absolute terms between the countries assessed, it is observable that they all present 
a decreasing trend which leads to a convergence with the way the industrial sectors of 19 OECD countries reduced their energy intensity during the 1990s [65].
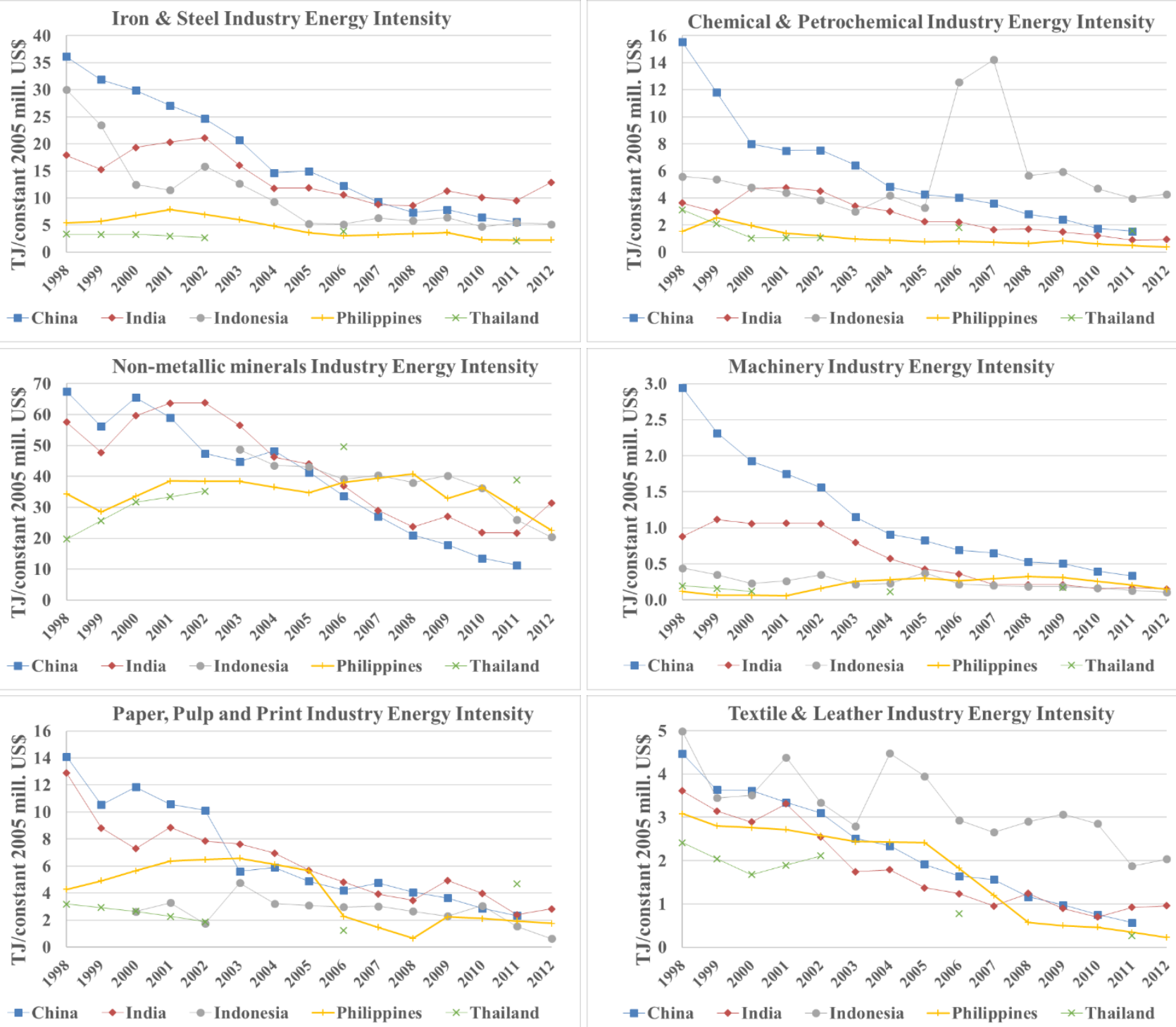

Fig. 7-12. Sectoral industrial energy intensity timeline of China, India, Indonesia, Philippines and Thailand 19982012. Data Source: $[63,64]$

However, not all industrial sectors are equal in terms of energy use and economic output and they present significant differences throughout the examined countries (Figures 7 to 12). Focusing on Indonesia, the Philippines and Thailand, a two-fold increase in energy intensity is found in the non-metallic minerals industry when compared to China. Indonesia has higher energy intensity in the chemical and petrochemical as well as the textile and leather industrial sectors comparing to the rest. Thailand has higher energy intensity in the paper, pulp and print industry.

Thailand, the Philippines and Indonesia hold an advantage over India when compared to China for the iron and steel industry, while for the chemical and petrochemical industry, India 
presents lower energy intensity levels than China. Only Indonesia shows significantly higher energy intensity than the rest of the countries by a three-fold figure at least for the most recent period. Further examination of the cement industry performance (non-metallic minerals), presents all the countries having higher energy intensity levels, when compared to China, by at least a two-fold margin; Thailand reaches a four-fold higher energy intensity, surpassing all other countries. In the machinery industrial sector though the figures present a reverse order. However, the energy intensity differences among the studied countries do not differ significantly and the energy requirements per economic output are low. Paper pulp and print industrial energy intensity shows that Thailand and India are more energy intense than China, while the Philippines and Indonesia present lower respective values. Textile and leather present a large margin between Indonesia and all the other countries including China by two-fold.

\subsection{Carbon Intensity}

Emissions intensity for total industry is presented in relation to economic output and consumed energy (Figure 13). India's emissions intensity per economic output is approximately 3 times higher than that of China and the Philippines, and almost 2 times higher when compared to Indonesia and the Philippines. China, Indonesia and India present a declining trend with China experiencing the steepest and most continuous decline.

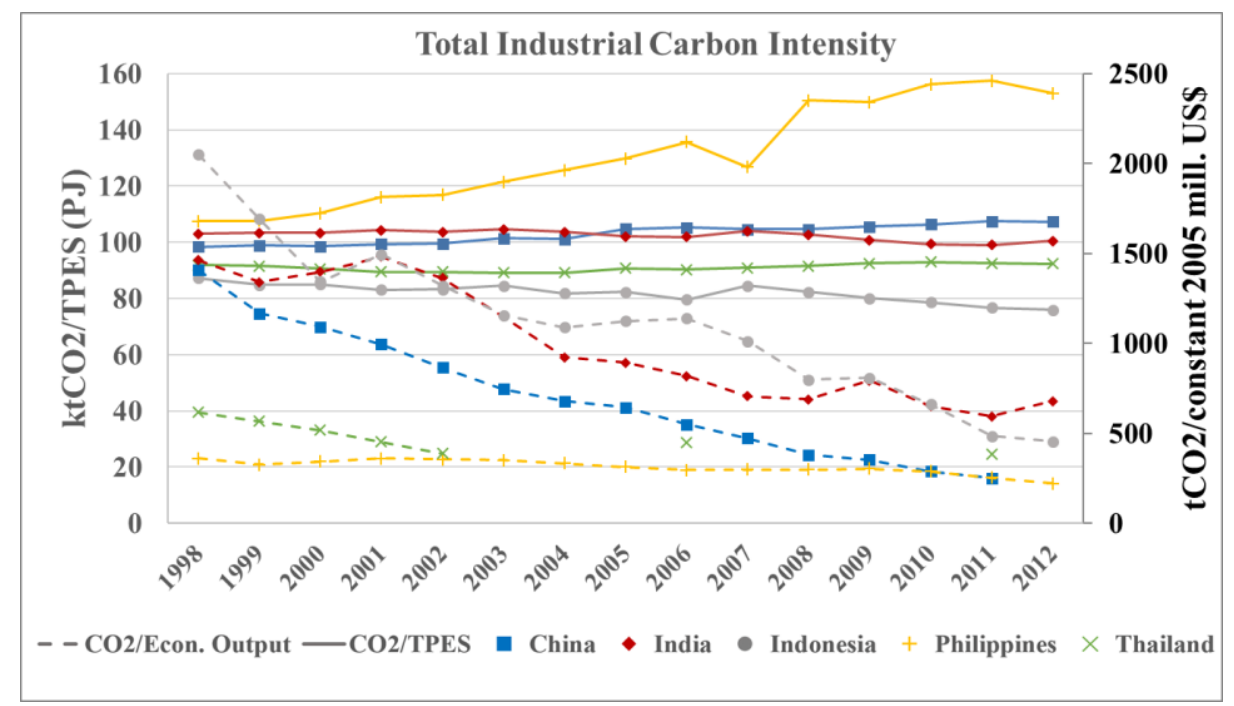

Fig. 13. Total industrial emissions intensity $\mathrm{CO}_{2} / \mathrm{million} \mathrm{US} \$ 2005$ and $\mathrm{ktCO}_{2} / \mathrm{PJ}$ timeline of China, India, Indonesia, the Philippines and Thailand 1998-2012. Data Source: [62,64,66] 
However, when comparing the emissions intensity per consumed energy, the trends appear to be stable for all countries but the Philippines. China and India produce approximately $30 \%$ higher $\mathrm{CO}_{2}$ emissions per energy input than that of Indonesia. Under that prism, the Philippines shows a vast divergence, with $60 \%$ higher emission intensity than India and approximately $55 \%$ higher than China.

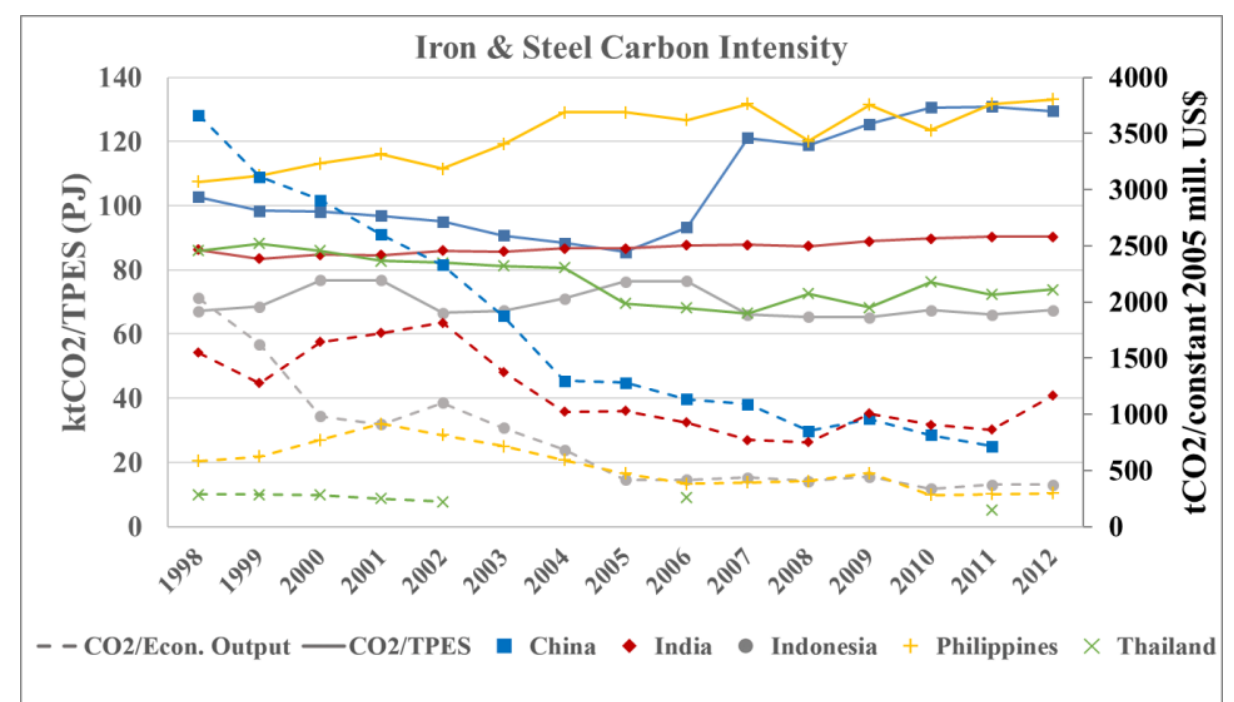

Fig. 14. Iron \& Steel emissions intensity $\mathrm{CO}_{2} /$ million US $\$ 2005$ and $\mathrm{ktCO}_{2} / \mathrm{PJ}$ timeline of China, India, Indonesia, the Philippines and Thailand 1998-2012. Data Source: [62,64,66]

While there is a wider electrification trend with innovative technologies in industry [67] and transport [68] it is necessary to look in more detail at the decomposed sectoral analysis. China's iron and steel (Figure 14) emissions intensity per economic output follows a steep decline between 1998 and 2004 and then continues on the same trend at a slower pace. India surpasses China in 2011 and stands at almost 3 times higher intensity than Indonesia and the Philippines. China and the Philippines present the highest emissions intensity per energy input, at approximately double the level of the other countries. 


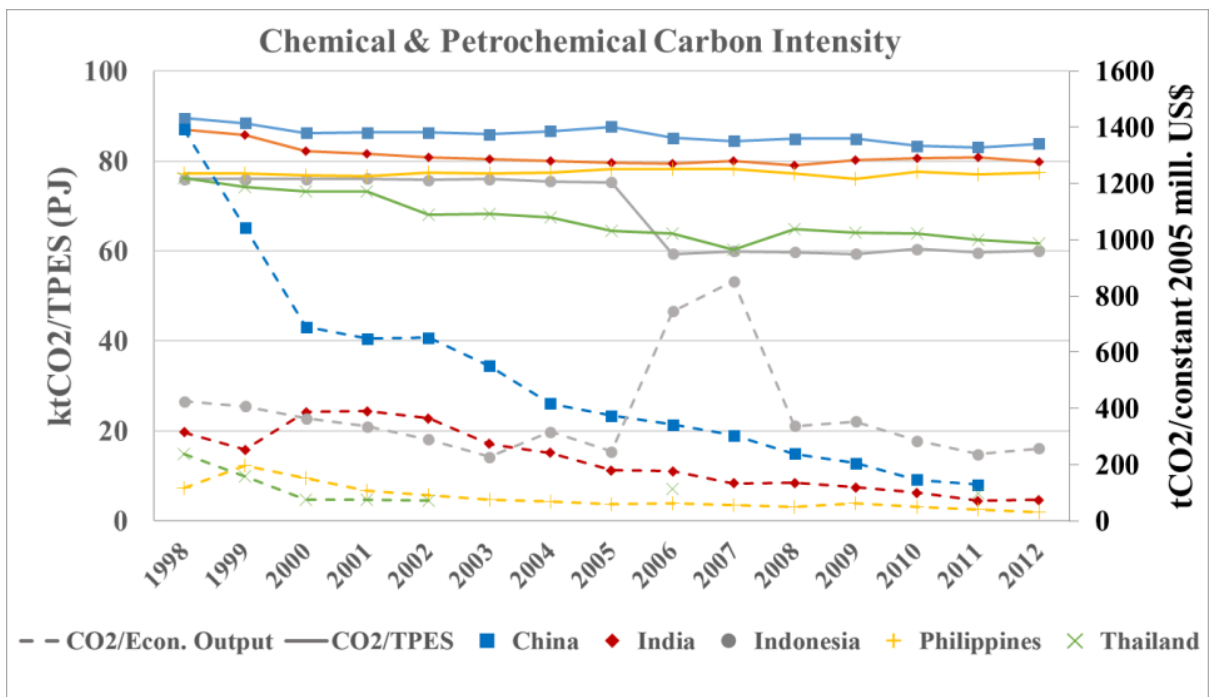

Fig. 15. Chemical \& Petrochemical emissions intensity $\mathrm{tCO}_{2} /$ million US $\$ 2005$ and $\mathrm{ktCO} / \mathrm{PJ}$ timeline of China, India, Indonesia, the Philippines and Thailand 1998-2012. Data Source: [62,64,66]

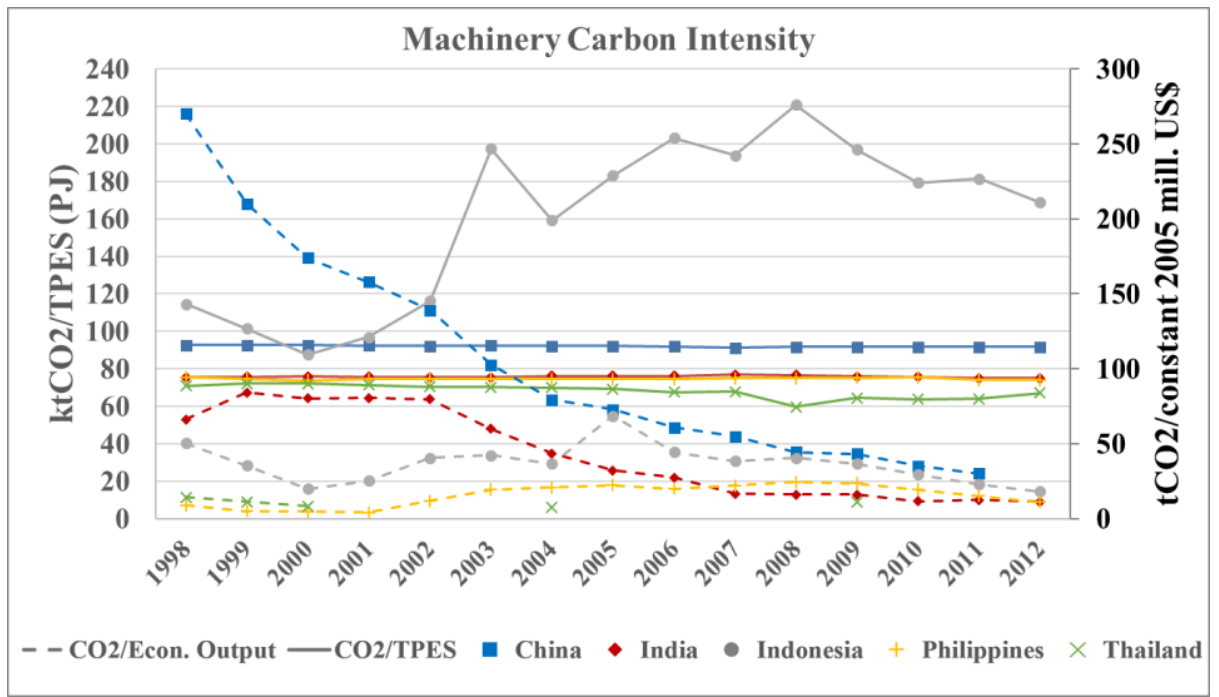

Fig. 16. Machinery emissions intensity $\mathrm{tCO}_{2} /$ million US\$ 2005 and $\mathrm{ktCO}_{2} / \mathrm{PJ}$ timeline of China, India, Indonesia, the Philippines and Thailand 1998-2012. Data Source: [62,64,66]

The emissions intensity in the chemical and petrochemical industry (Figure 15) shows Indonesia having the highest emissions intensity per economic output among the rest of the countries, surpassing China and India by two-fold and three-fold respectively. However, China, India and the Philippines have the highest emissions intensity per energy input with Indonesia and Thailand having an approximately 35\% lower intensity.

Similarly, the trend of Chinese emissions intensity per economic output for the machinery industry (Figures 16) presents a continuous declining trend. However, China is the most emission intense country per economic output, averaging a 30\% higher rate than India for 20082011. The rest of the examined countries present a high convergence since 2007. All countries 
apart from Indonesia present negligible changes in their emissions intensity per energy input. Indonesia presents 50-60\% higher emissions intensity than China.

Focusing on non-metallic minerals industry (Figures 17) when examined on an economic output basis, the most intense countries are Thailand and the Philippines. Those countries have a significantly higher intensity than China by almost four and two-fold respectively. India has the highest emissions intensity per energy unit, but its difference to China is narrow averaging at $13 \%$.

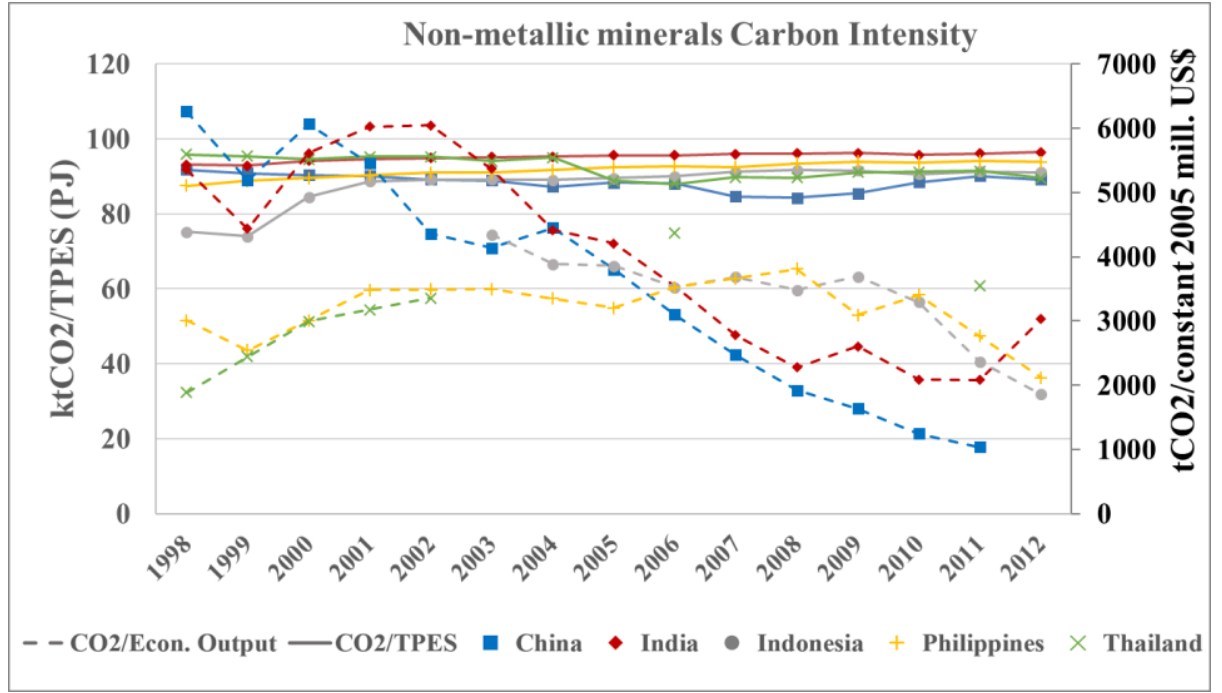

Fig. 17. Non-metallic minerals emissions intensity $\mathrm{tCO}_{2} /$ million US $\$ 2005$ and $\mathrm{ktCO}_{2} / \mathrm{PJ}$ timeline of China, India, Indonesia, the Philippines and Thailand 1998-2012. Data Source: [62,64,66]

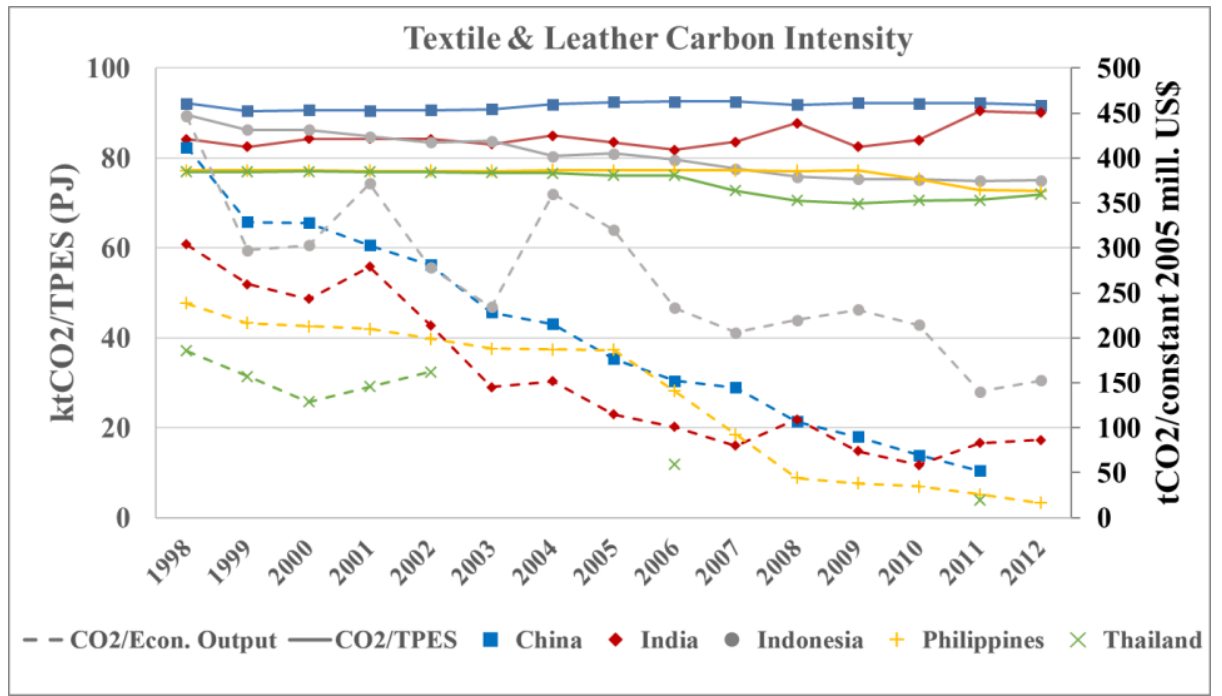

Fig. 18. Textile \& Leather emissions intensity $\mathrm{tCO}_{2} /$ million US $\$ 2005$ and $\mathrm{ktCO}_{2} / \mathrm{PJ}$ timeline of China, India, Indonesia, the Philippines and Thailand 1998-2012. Data Source: [62,64,66]

In textile and leather industries, Indonesia has the highest emissions intensity per economic output (Figure 18), approximately 55\% higher than India, three-fold higher than China and sixfold higher than the Philippines. China and India have the highest emissions intensity. 
Carbon dioxide per economic output in the paper, pulp and print industrial sector (Figure 19) presents mixed emission intensity between the examined countries throughout 1998-2012. Nevertheless, China's intensity per economic output has been in continuous decline and was surpassed by India in 2009. India retains the highest intensity, almost three-fold higher than Indonesia.

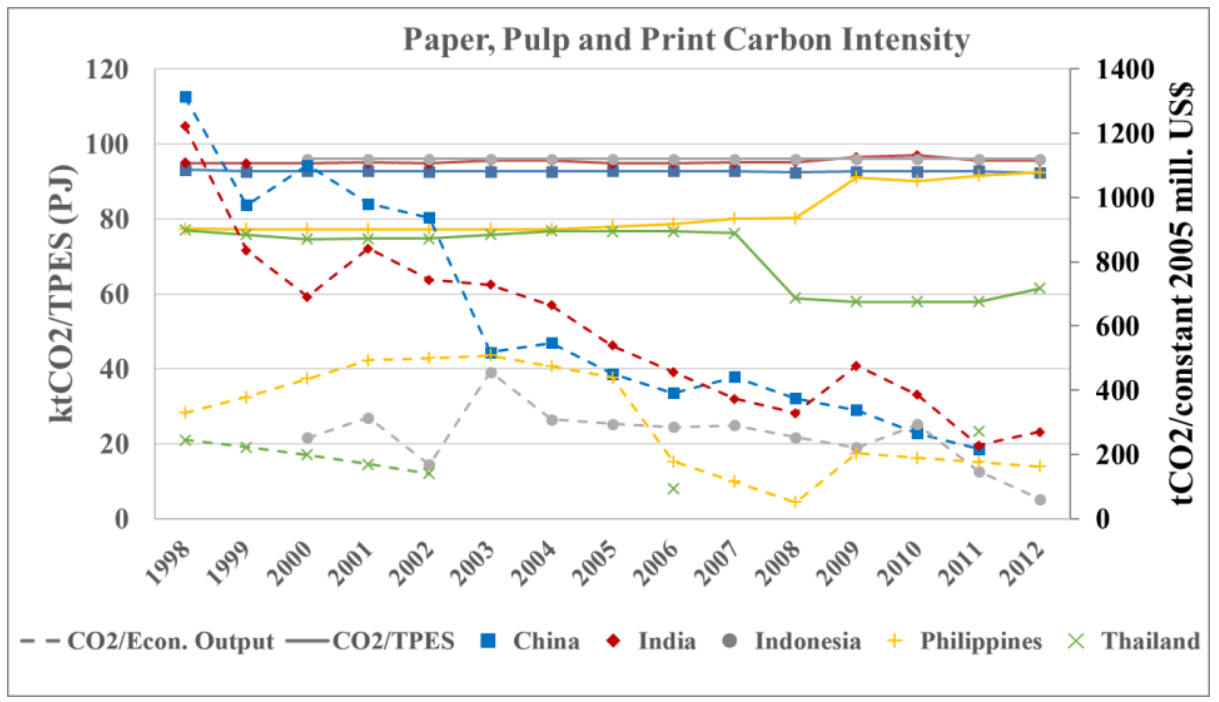

Fig. 19. Paper, pulp and print emissions intensity $\mathrm{tCO}_{2} /$ million US $\$ 2005$ and $\mathrm{ktCO}_{2} / \mathrm{PJ}$ timeline of China, India, Indonesia, the Philippines and Thailand 1998-2012. Data Source: [62,64,66]

\section{Discussion of the Results}

\subsection{Energy intensity results}

Understanding the interplay of the key variables and the emerging patterns is a key focus of this research. We find that gradual energy intensity reduction is commonplace among all industries and countries. Besides that observation, specific industries do not present universal energy intensity reduction patterns, which appear to be country specific.

The largest consumers of primary commercial energy in India are the power and industry sectors [53]. As any coal-based power sector that of India is responsible for the emission of air pollution and greenhouse gases [69]. However, amongst the most energy consuming industrial sectors in the country are aluminium and cement (non-metallic minerals), and the leading industry in energy consumption is iron and steel.

India's energy intensity per economic output is significantly higher than that of China which presents the urgency for innovation that will lower energy costs and maximize profit margins. The share of added value that originates from the industrial sector is expected to climb at $25 \%$ of India's total GDP by 2030 [70] from approximately 8\% in 2013 according to the World 
Bank WDI. Competitive advantages such as a large working-age population that reaches $70 \%$ of the total [16], low labour costs and social expenditure [71] while maintaining a significant innovation potential $[72,73]$ incentivise manufacturers to turn their production focus from China to India and Indonesia despite that leading to increased energy use.

While looking at the disaggregation of specific industrial sectors, emissions control is important predominantly within the industrial and energy sectors as improvements in other sectors, such as transport, mainly concern electrification which can be entirely ineffective without decarbonization [68].

Evidently, the non-metallic minerals sector in India, Indonesia, the Philippines and Thailand presents a significantly higher energy intensity than in China. Also, India presents higher energy intensity than China in the iron and steel industrial sector. The share of these two industrial sectors in total energy use, reaching more than $45 \%$, makes them a pressing priority as a potential transition from China to India would result in significant emissions growth.

Subsequently, energy intensity reduction can be achieved with improving and modernising the technologies used in production processes. Improvement of the energy intensity of the paper, pulp and print industry is feasible through making the kraft process used in paper mills more efficient. That is achieved by utilizing cogeneration; making the paper mills net exporters of electricity and heat [74]. Improvement on energy intensity can also be achieved through the introduction of fuels that can be used in higher efficiency combustion cycles; bark and bunker oil have combustion energy efficiency reaching $67 \%$ and $80 \%$ respectively [75]. Iron and steel industries, follow a common path of using ore and coke in blast furnaces for producing pig iron, then processed in basic oxygen furnaces (BOF) or the least efficient open-hearth furnaces $(\mathrm{OHF})$. Smelt and direct reduction (DR) are more advanced processes of iron production, with the electric arc furnace (EAF) mostly using scrap to produce steel. Options of improving energy intensity in the industry have different time frame availabilities, such as pulverized coal and plastic waste injection in the short term and hydrogen flash melting in the medium term [76]. Technological innovation can provide solutions to improving energy efficiency directly but must be supported by bold policies in the same direction $[67,77]$.

\subsection{Carbon intensity results}

Carbon intensity per economic output presents similar patterns to those of energy intensity precisely because of their common denominator in monetary units. The gradual reduction 
observed does not depend on industry. We also find that carbon intensity per energy output does not present any distinct pattern regardless of industry or country.

The continuous steep decline in China's carbon intensity per economic output (Section 3) is a result of central organization and robust policies applied in the country [78,79]. Discussing carbon intensity per energy input, the divergence that the Philippines show has its origins in the increasingly coal reliant fuel mix between 1994-2014 which resulted in an eight-fold increase in $\mathrm{CO}_{2}$ emissions originating from its coal fuel mix and the use of blast furnace gas fuel [80].

The Indian iron and steel industry is accounted as the third largest iron and steel industry in the world, surpassing that of the Unites States in total crude steel production in 2015 by 10,181 metric tons [81]. Focusing on processing technologies being used in the Indian iron and steel sector, the domestic availability of coal combined with its lower price when compared to natural gas, leads to the usage of coal-based direct reduced iron feedstocks (DRI) supplying blast furnace - basic oxygen furnaces (BOF) and electric arc furnaces (EAF) [82]. Classifying the carbon dioxide emissions of metallurgical processes used in India, EAF on steel scrap which follows an increasing trend in capacity, has the lowest carbon footprint due to not requiring coal and coke as reducing agents [83]. Blast furnace BOF and EAF DRI have an intermediate position [84], providing an explanation to India's average $\mathrm{CO}_{2} / \mathrm{PJ}$ performance (Figure 14). The production of iron and steel based on BF and BF BOF technologies is evident in China and the Philippines. This route of production has differences both in carbon and energy intensity when compared to EAF. Blast furnace BOF requires 0.5 tonnes of coal equivalent (tce) per tonne compared to $0.3 \mathrm{tce} / \mathrm{t}$ of EAF [85] and emits $2.1 \mathrm{tCO}_{2} / \mathrm{t}$ compared to $0.6 \mathrm{tCO}_{2} / \mathrm{t}$ respectively [86]. China has been unable to increase its EAF production short-term due to imposed scrap price limits [87] but the scrap supply share is expected to increase sharply in the next years [88].

Diversity in the industrial fuel mix is not widespread throughout all Chinese industrial activities. The non-metallic minerals industrial sector demonstrates a high reliance on bituminous coal, similarly to the reliance of the same sector in India. India and China, the largest cement producers in the world, make use of rotary dry kilns [89] which can be improved by adopting a range of technological interventions for cement production [90]. These include blended cement with additives that lower the clinker content and kiln shell heat loss reduction, presenting the highest improvement amongst other optimisation processes [89]. Moreover, a reduction of clinker content in cement is achievable through granulated blast furnace slags (GFBS), a common practice in Europe which is feasible in developing countries [91]. The 
discussed increase in efficiency can also be extended for the case of other countries such as Thailand, a country that makes exclusive use of dry kiln processes [92].

Excessive use of specific types of coal such as lignite and other bituminous fuels, classify China and India as the countries with the highest carbon intensity $\left(\mathrm{CO}_{2} / \mathrm{PJ}\right)$ level in the textile and leather industries. Their reliance on satisfying production requirements with coal products, results in significant carbon intensity divergence from Indonesia, the Philippines and Thailand.

It should be noted that the converging Chinese, Indian and Indonesian carbon intensity per energy input of the paper, pulp and print industry implies a technological and fuel mix convergence. Future production process technologies that can lower carbon intensity in that sector, involve a more efficient drying technology in medium term or black liquor gasification to be introduced in the long term [76].

\section{Conclusions}

We find that the potential relocation of industrial activities from China to India and SE Asian countries under an emissions intensity prism will alter the energy use and emissions output depending on the industrial sector in focus. In response to our initial hypotheses, we find that:

H1: Even when focusing on the individual industrial sectors, our examined countries present significantly different energy intensity for every one of the examined years; therefore, confirming this hypothesis (Figures 6-12).

H2: Despite substantial energy intensity differences even in our latest examined year, for all industrial sectors we find that energy intensity converges significantly over time; therefore, confirming this hypothesis (Figures (6-12).

H3: As expected, because of their estimation parameter differences carbon intensity per economic output and carbon intensity per energy used present different patterns over time; therefore, confirming this hypothesis (Figures 13-19).

H4: While carbon intensity per economic output converges over time for all industrial sectors, we find that carbon intensity per energy used does not present converging results for any of the examined industries; therefore, confirming this hypothesis (Figures 13-19).

China demonstrates a stable trend of reducing emissions intensity per economic output, despite an overall growth in living standards and non-industry consumer consumption, due to factors such as increased energy efficiency [93,94]. However, its high emission intensity per energy input in many of the industrial sectors is a determinant of technological structure being orientated towards high energy consumption [95]. 
Expanding this research to an energy per economic output basis consideration with the disaggregated energy intensity of the industrial sectors in China, India, Indonesia, the Philippines and Thailand further conclusions can be extracted. We find that although generally India's industrial energy intensity is double that of China, it is the iron and steel and the nonmetallic mineral sectors, that are responsible for that difference. Looking at Indonesia, the Philippines and Thailand, the non-metallic minerals industry presents at least twice higher energy intensity than China. Indonesia has higher energy intensity in the chemical and petrochemical as well as the textile and leather industry. Thailand has higher energy intensity in the paper pulp and print industry while in iron and steel and textile and leather industries, the Philippines present lower energy intensity. It is essential that emissions control is being looked at predominantly within the industrial and energy sectors to facilitate the scope of sustainability in industrial parks which can act even in isolation of the country-wide systems [96,97].

Regional policies might be best suited to maintain an optimal balance between economic and industrial development and a stronger driver for technological innovation and knowledge transfer [98]. Regional markets with innovative technologies have the capacity to facilitate progress while not compromising emission control commitments [99]. With focus on the policy implications of our work on the Paris Agreement [100] and the respective INDC planning for the examined countries our results highlight that industrial relocation could signal differentiated levels of industrial competitiveness and affect the industries by national environmental agendas and future relevant policies [100-105]. As the energy and carbon intensity per economic output depend extensively on a country's economic structure and its technological and technical capabilities, governments should prioritise private-public investment partnerships to facilitate industrial technological leaps. Technological advancement will lay the ground for deeper structural industrial changes and enable countries to escape fuelmix lock-ins on incumbent industries.

Quantitative limitations of this research include a limited availability of primary data; crossreferencing raw primary fuel in each coal product and net calorific value data in detail for extended timelines is available in a very limited range of databases. In a wider context, carbon dioxide emissions due to industrial cross-country shift, energy and carbon intensity indicators are not the exclusive drivers responsible for mitigating carbon dioxide emissions. A concrete case of carbon dioxide emissions determinants should additionally take into account indicators such as the labour productivity, industrial scale and energy structure effect in the industry concluding in their proportional significance. 
Further research is necessary to decompose the factors driving emissions in the specific industrial sectors of the examined countries. This includes an index decomposition approach which could determine and quantify the effect that energy and carbon intensity have as carbon dioxide emission drivers, and establish their effect in proportion to other parameters and their econometric testing. Furthermore, we suggest the exploration of the potential learning curves for industrial improvements in emissions intensity across different industrial sectors and the role of factors such as indigenous fuel availability, industrial economies of scale and commitment to emissions reduction. Finally, extended research should additionally focus on the role of industrial electrification and subsequently the electrification options and decisions [106] that are required to control and impact on energy and industrial emissions intensity. This may further spring interest in the innovation interplay between utilities and energy users [107].

\section{Acknowledgements}

The specific study has been funded under the project TILOS (Horizon 2020 Low Carbon Energy Local / small-scale storage LCE-08-2014). This project has received funding from the European Union \& Horizon 2020 research and innovation programme under Grant Agreement No 646529.

\section{References}

[1] IMF. World Economic Outlook: Gaining Momentum? Washington, DC: International Monetary Fund; 2017.

[2] IMF Communications Department. IMF Staff Completes 2016 Article IV Mission to Indonesia 2016.

[3] IMF. 2016 Article IV Consultation - Press Release; Staff Report; and Statement By the Executive Director for Thailand. vol. 139. 2016.

[4] IMF. Philippines: Staff Report for the 2016 Article IV Consultation. 2016.

[5] IMF. Subdued Demand, Diminished Prospects, World Economic Outlook Update 2016:1-2. http://www.imf.org/external/pubs/ft/weo/2016/update/01/pdf/0116.pdf.

[6] IMF. World Economic Outlook Update - An update of the key WEO projections. Davos: 2018.

[7] Fingar C. India knocks China from top of FDI league table - FT.com. Financ Times 2016.

[8] Iyengar R. India Has Overtaken the U.S. and China to Top Spot in a Key World Foreign Investment Table. Time 2015. 
[9] Chalvatzis KJ, Ioannidis A. Energy Supply Security in Southern Europe and Ireland. Energy Procedia 2016;105:3656-62. doi:10.1016/j.egypro.2017.03.660.

[10] Donaldson T. China Factory Owners Look to India for Relocation as Costs Rise Sourcing Journal. Sourc J 2016. https://sourcingjournalonline.com/china-factoryowners-look-india-relocation-costs-rise/ (accessed April 29, 2017).

[11] Chu K. China Manufacturers Survive by Moving to Asian Neighbors - WSJ. Wall Str J 2013.

https://www.wsj.com/articles/SB10001424127887323798104578453073103566416 (accessed April 29, 2017).

[12] de Vera BO. More firms relocating to Philippines, M'sia, Indonesia - Business - The Jakarta Post. Jakarta Post 2014.

http://www.thejakartapost.com/news/2014/08/28/more-firms-relocating-philippinesmsia-indonesia.html (accessed April 29, 2017).

[13] HKTDC Research. The search for low-cost production bases in Southeast Asia | Hong Kong Means Business 2013. http://hkmb.hktdc.com/en/1X09U0V5/hktdcresearch/The-search-for-low-cost-production-bases-in-Southeast-Asia (accessed January 20, 2017).

[14] Yang C. Relocating labour-intensive manufacturing firms from China to Southeast Asia: a preliminary investigation. Bandung J Glob South 2016;3:3. doi:10.1186/s40728-016-0031-4.

[15] Kanchana K, Unesaki H. ASEAN energy security: An indicator-based assessment. Energy Procedia 2014;56:163-71. doi:10.1016/j.egypro.2014.07.145.

[16] Chomik R, Piggott J. Asia in the ageing century: Part I - Population trends 2013:1-18.

[17] Zhai W, Sun S, Zhang G. Reshoring of American manufacturing companies from China. Oper Manag Res 2016;9:62-74. doi:10.1007/s12063-016-0114-z.

[18] Zheng D, Shi M. Multiple environmental policies and pollution haven hypothesis: Evidence from China's polluting industries. J Clean Prod 2017;141:295-304. doi:10.1016/j.jclepro.2016.09.091.

[19] Chang G, Jiang C, Chang K, Alam B. Land Prices and Intracountry Industrial Relocation in China. Chinese Econ 2013;46:54-73. doi:10.2753/CES10971475460203.

[20] Policy Department Economic and Scientific Policy. Relocation of EU Industry An Overview of Literature Background Note. 2006.

[21] Fan R, Luo M, Zhang P. A study on evolution of energy intensity in China with heterogeneity and rebound effect. Energy 2016;99:159-69. doi:http://dx.doi.org/10.1016/j.energy.2016.01.041.

[22] Xu L, Chen N, Chen Z. Will China make a difference in its carbon intensity reduction targets by 2020 and 2030? Appl Energy 2017;203:874-82. doi:10.1016/j.apenergy.2017.06.087.

[23] Narayan S. Predictability within the energy consumption-economic growth nexus: Some evidence from income and regional groups. Econ Model 2016;54:515-21. doi:10.1016/j.econmod.2015.12.037. 
[24] Chiou-Wei SZ, Chen C-F, Zhu Z. Economic growth and energy consumption revisited - Evidence from linear and nonlinear Granger causality. Energy Econ 2008;30:306376. doi:10.1016/j.eneco.2008.02.002.

[25] Azam M, Khan AQ, Bakhtyar B, Emirullah C. The causal relationship between energy consumption and economic growth in the ASEAN-5 countries. Renew Sustain Energy Rev 2015;47:732-45. doi:10.1016/j.rser.2015.03.023.

[26] OECD. Industrial production (indicator) 2017. doi:10.1787/39121c55-en.

[27] Eichhammer W, Walz R. Industrial energy efficiency and competitiveness. 2011.

[28] Sanstad AH, Roy J, Sathaye JA. Estimating energy-augmenting technological change in developing country industries. Energy Econ 2006;28:720-9. doi:10.1016/j.eneco.2006.07.005.

[29] Voigt S, De Cian E, Schymura M, Verdolini E. Energy intensity developments in 40 major economies: Structural change or technology improvement? Energy Econ 2014;41:47-62. doi:10.1016/j.eneco.2013.10.015.

[30] Sadorsky P. Do urbanization and industrialization affect energy intensity in developing countries? Energy Econ 2013;37:52-9. doi:10.1016/j.eneco.2013.01.009.

[31] Forin S, Radebach A, Steckel JC. The effect of industry delocalization on global energy use: A global sectoral perspective Silvia. Energy Econ 2017;70:233-43. doi:10.1016/j.eneco.2017.12.031.

[32] Tan R, Lin B. What factors lead to the decline of energy intensity in China's energy intensive industries? Energy Econ 2018;71:213-21. doi:10.1016/j.eneco.2018.02.019.

[33] Duan H, Mo J, Fan Y, Wang S. Achieving China's energy and climate policy targets in 2030 under multiple uncertainties. Energy Econ 2018;70:45-60.

doi:10.1016/j.eneco.2017.12.022.

[34] Gómez DR, Watterson JD, Americanohia BB, Ha C, Marland G, Matsika E, et al. Chapter 2: Stationary Combustion. 2006 IPCC Guidel Natl Greenh Gas Invent 2006:47. doi:10.1016/S0166-526X(06)47021-5.

[35] Grubb M, Butler L, Feldman O. Analysis of the Relationship between Growth in Carbon Dioxide Emissions and Growth in Income 2004.

[36] Grubb M, Muller B, Butter L. The relationship between carbon dioxide emissions and economic growth. Univ Cambridge Appl Econ 2004:1-19.

[37] International Energy Agency. Energy Technology Perspectives 2012. 2012. doi:10.1787/energy_tech-2012-en.

[38] Chalvatzis KJ, Ioannidis A. Energy supply security in the EU: Benchmarking diversity and dependence of primary energy. Appl Energy 2017;207:465-76. doi:10.1016/j.apenergy.2017.07.010.

[39] Wang C. Changing energy intensity of economies in the world and its decomposition. Energy Econ 2013;40:637-44. doi:10.1016/j.eneco.2013.08.014.

[40] Pappas D, Chalvatzis KJ. Energy and Industrial Growth in India : The Next Emissions Superpower? Energy Procedia 2016;0:3656-62. doi:10.1016/j.egypro.2017.03.842. 
[41] De Felice F, Petrillo A, Silvestri A. Offshoring: Relocation of production processes towards low-cost countries through the project management \& process reengineering performance model. Bus Process Manag J 2015;21:379-402. doi:10.1108/BPMJ-012014-0008.

[42] United Nations Sustainable Development Division. Intensity of Energy Use, Total and by Economic Activity. 2005.

[43] European Environment Agency. Energy intensity 2015.

[44] United Nations Sustainable Development Division. Intensity of Energy Use, Total and by Economic Activity. 2005.

[45] Department of Energy. Energy Intensity Indicators: Terminology and Definitions. Off Energy Effic Renew Energy n.d. http://energy.gov/eere/analysis/energy-intensityindicators-terminology-and-definitions (accessed September 10, 2016).

[46] International Energy Agency. India (key partner country). Non-Member Ctries 2016. https://www.iea.org/countries/non-membercountries/india/ (accessed September 12, 2016).

[47] International Energy Agency. Energy Statistics of Non OECD Countries. Conversion Factors 1971-2013. UK Data Serv 2014. doi:http://dx.doi.org/10.5257/iea/esnon/2014.

[48] Shan Y, Liu J, Liu Z, Xu X, Shao S, Wang P, et al. New provincial CO2 emission inventories in China based on apparent energy consumption data and updated emission factors. Appl Energy 2016. doi:10.1016/j.apenergy.2016.03.073.

[49] Liu Z, Guan D, Wei W, Davis SJ, Ciais P, Bai J, et al. Reduced carbon emission estimates from fossil fuel combustion and cement production in China. Nature 2015;524:335-8. doi:10.1038/nature14677.

[50] Jiang X, Guan D. Determinants of global CO2 emissions growth. Appl Energy 2016:1-10. doi:10.1016/j.apenergy.2016.06.142.

[51] Alam MM, Murad MW, Noman AHM, Ozturk I. Relationships among carbon emissions, economic growth, energy consumption and population growth: Testing Environmental Kuznets Curve hypothesis for Brazil, China, India and Indonesia. Ecol Indic 2016;70:466-79. doi:10.1016/j.ecolind.2016.06.043.

[52] Timilsina GR, Shrestha A. Transport sector CO2 emissions growth in Asia: Underlying factors and policy options. Energy Policy 2009;37:4523-39. doi:10.1016/j.enpol.2009.06.009.

[53] Indian Ministry of Statistics and Programme Implementation. Energy Statistics 2015. New Delhi: 2015.

[54] International Energy Agency. Summary Energy Balances: World Energy Balances, 1960-2013. 2014. doi:http://dx.doi.org/10.5257/iea/web/2014.

[55] International Energy Agency. Energy Statistics of Non OECD Countries. Energy Statistics 1971-2013. UK Data Serv 2014. doi:http://dx.doi.org/10.5257/iea/esnon/2014.

[56] United Nations Industrial Development Organization. Compilation of energy statistics for economic analysis. 2010. 
[57] Bureau of Labor Statistics. CPI Inflation Calculator. Databases, Tables Calc by Subj 2016. http://www.bls.gov/data/inflation_calculator.htm (accessed September 11, 2016).

[58] Li JS, Chen GQ. Energy and greenhouse gas emissions review for Macao. Renew Sustain Energy Rev 2013;22:23-32. doi:10.1016/j.rser.2012.11.072.

[59] Torrie RD, Stone C, Layzell DB. Understanding Energy Systems Change in Canada: 1. Decomposition of Total Energy Intensity. Energy Econ 2016;56:101-6. doi:10.1016/j.eneco.2016.03.012.

[60] Department of Energy. Energy Intensity Indicators: Terminology and Definitions. Off Energy Effic Renew Energy n.d.

[61] IPCC. Mitigation of climate change: Contribution of working group III to the fourth assessment report of the Intergovernmental Panel on Climate Change. 2007.

[62] IPCC. 2006 IPCC Guidelines for National Greenhouse Gas Inventories. Main 2006;2:12. doi:http://www.ipcc-

nggip.iges.or.jp/public/2006gl/pdf/2_Volume2/V2_3_Ch3_Mobile_Combustion.pdf.

[63] International Energy Agency. Key World Energy Statistics 2015 2015:81. doi:10.1787/9789264039537-en.

[64] United Nations Industrial Development Organization. INDSTAT2 Industrial Statistics Database (Edition: 2016). UK Data Service. 2016. doi:http://dx.doi.org/10.5257/unido/indstat2/2016.

[65] Mulder P. International specialization, sector structure and the evolution of Manufacturing energy intensity in OECD countries. Energy J 2015;36:111-36. doi:10.5547/01956574.36.3.4.

[66] International Energy Agency. IEA Statistics. CO2 Emissions From Fuel Combustion: Highlights. 2015. doi:http://dx.doi.org/10.5257/iea/co2/2015.

[67] Zafirakis D, Elmasides C, Sauer DU, Leuthold M, Merei G, Kaldellis JK, et al. The multiple role of energy storage in the industrial sector: Evidence from a Greek industrial facility. Energy Procedia 2014;46:178-85.

doi:10.1016/j.egypro.2014.01.171.

[68] Hofmann J, Guan D, Chalvatzis K, Huo H. Assessment of electrical vehicles as a successful driver for reducing CO2 emissions in China. Appl Energy 2016. doi:10.1016/j.apenergy.2016.06.042.

[69] Kaldellis J, Spyropoulos G, Chalvatzis K. The impact of greek electricity generation sector on the national air pollution problem. Fresenius Environ Bull 2004;13:647-56.

[70] PwC. Future of India - The Winning Leap. 2014.

[71] Grinin L, Tsirel S, Korotayev A. Will the explosive growth of China continue? Technol Forecast Soc Change 2014;95:297. doi:10.1016/j.techfore.2014.06.023.

[72] Thornton I. The fruits of frugal innovation. Green Futur Mag 2013.

[73] Cooper RG. The State of Product Development. Res Manag 2009;52:6.

[74] Jönsson J, Algehed J. Pathways to a sustainable European kraft pulp industry: Trade- 
offs between economy and $\mathrm{CO} 2$ emissions for different technologies and system solutions. Appl Therm Eng 2010;30:2315-25.

doi:10.1016/j.applthermaleng.2010.01.025.

[75] Musa C, Licheri R, Locci AM, Orrù R, Cao G, Rodriguez MA, et al. Energy efficiency during conventional and novel sintering processes: the case of Ti-Al2O3-TiC composites. J Clean Prod 2009;17:877-82. doi:10.1016/j.jclepro.2009.01.012.

[76] Bassi AM, Yudken JS, Ruth M. Climate policy impacts on the competitiveness of energy-intensive manufacturing sectors. Energy Policy 2009;37:3052-60. doi:10.1016/j.enpol.2009.03.055.

[77] Murphy R. The emerging hypercarbon reality, technological and post-carbon utopias, and social innovation to low-carbon societies. Curr Sociol 2014;63:317-38. doi:10.1177/0011392114551757.

[78] Chalvatzis KJ, Rubel K. Electricity portfolio innovation for energy security: The case of carbon constrained China. Technol Forecast Soc Change 2015;100:267-76. doi:10.1016/j.techfore.2015.07.012.

[79] Chalvatzis KJ. Electricity generation development of Eastern Europe: A carbon technology management case study for Poland. Renew Sustain Energy Rev 2009;13:1606-12. doi:10.1016/j.rser.2008.09.019.

[80] IEA. Statistics: CO2 emissions from fuel combustion highlights (2016 edition). 2016.

[81] WSA. Steel Statistical Yearbook 2016. WorldSteel Assoc 2016:128.

[82] Morrow WR, Hasanbeigi A, Sathaye J, Xu T. Assessment of energy efficiency improvement and $\mathrm{CO} 2$ emission reduction potentials in India's cement and iron \& steel industries. J Clean Prod 2014;65:131-41. doi:10.1016/j.jclepro.2013.07.022.

[83] Kuramochi T. Assessment of midterm $\mathrm{CO} 2$ emissions reduction potential in the iron and steel industry: a case of Japan. J Clean Prod 2016;132:81-97. doi:10.1016/j.jclepro.2015.02.055.

[84] Lisienko VG, Chesnokov YN, Lapteva A V., Noskov VY. Types of greenhouse gas emissions in the production of cast iron and steel. IOP Conf Ser Mater Sci Eng 2016;150. doi:10.1088/1757-899X/150/1/012023.

[85] Wen Z, Meng F, Chen M. Estimates of the potential for energy conservation and CO2 emissions mitigation based on Asian-Pacific Integrated Model (AIM): The case of the iron and steel industry in China. J Clean Prod 2014;65:120-30. doi:10.1016/j.jclepro.2013.09.008.

[86] Yellishetty M, Mudd GM, Ranjith PG, Tharumarajah A. Environmental life-cycle comparisons of steel production and recycling: Sustainability issues, problems and prospects. Environ Sci Policy 2011;14:650-63. doi:10.1016/j.envsci.2011.04.008.

[87] Wübbeke J, Heroth T. Challenges and political solutions for steel recycling in China. Resour Conserv Recycl 2014;87:1-7. doi:10.1016/j.resconrec.2014.03.004.

[88] Wang P, Jiang Z, Geng X, Hao S, Zhang X. Quantification of Chinese steel cycle flow: Historical status and future options. Resour Conserv Recycl 2014;87:191-9. doi:10.1016/j.resconrec.2014.04.003. 
[89] Morrow WR, Hasanbeigi A, Sathaye J, Xu T. Assessment of energy efficiency improvement and $\mathrm{CO} 2$ emission reduction potentials in India's cement and iron \& steel industries. J Clean Prod 2014;65:131-41. doi:10.1016/j.jclepro.2013.07.022.

[90] Ray S. Econometric Analysis of Efficiency in Indian Cement Industry 2011;1:11-23.

[91] CSI/ECRA. Development of State of the Art-Techniques in Cement Manufacturing: Trying to look ahead. Technol Pap 2009:99.

[92] Hasanbeigi A, Menke C, Therdyothin A. The use of conservation supply curves in energy policy and economic analysis: The case study of Thai cement industry. Energy Policy 2010;38:392-405. doi:10.1016/j.enpol.2009.09.030.

[93] Pothitou M, Hanna RF, Chalvatzis KJ. Environmental knowledge, pro-environmental behaviour and energy savings in households: An empirical study. Appl Energy 2016;184:1217-29. doi:10.1016/j.apenergy.2016.06.017.

[94] Pothitou M, Hanna RF, Chalvatzis KJ. ICT entertainment appliances' impact on domestic electricity consumption. Renew Sustain Energy Rev 2017;69:843-53. doi:http://dx.doi.org/10.1016/j.rser.2016.11.100.

[95] Yuan P, Cheng S. Determinants of carbon emissions growth in China: A structural decomposition analysis. Energy Procedia 2011;5:169-75.

doi:10.1016/j.egypro.2011.03.030.

[96] Spyropoulos G, Chalvatzis K, Paliatsos A, Kaldellis JK. Sulphur Dioxide Emissions Due to Electricity Generation in the Aegean Islands: Real Threat or Overestimated Danger? 9th Int. Conf. Environ. Sci. Technol., 2005.

[97] Zafirakis D, Chalvatzis KJ. Wind energy and natural gas-based energy storage to promote energy security and lower emissions in island regions. Fuel 2014;115:203-19. doi:10.1016/j.fuel.2013.06.032.

[98] Kaldellis JK, Chalvatzis KJ. Environment and Industrial Development: Sustainability and Development. Air Pollut. 1st ed., Athens: Stamoulis Publications; 2005.

[99] Zafirakis D, Chalvatzis KJ, Baiocchi G. Embodied CO2 emissions and cross-border electricity trade in Europe: Rebalancing burden sharing with energy storage. Appl Energy 2015;143:283-300. doi:10.1016/j.apenergy.2014.12.054.

[100] United Nations. Adoption of the Paris Agreement. Conf Parties Its Twenty-First Sess 2015;21932:32.

[101] Republic of Indonesia. Intended National Determined Contribution to the UNFCC 2015:1-8.

[102] UNFCCC. India's Intended National Determined Contributions 2015:1-38.

[103] National Development and Reform Commission of China. Enhanced Actions on Climate Change: China's intended nationally determined contributions. Unfecc 2015:36. doi:http://www4.unfccc.int/submissions/INDC/Published\%20Documents/China/1/Chi na's\%20INDC\%20-\%20on\%2030\%20June\%202015.pdf.

[104] Office of Natural Resources and Environmental Policy. Thailand's Intended Nationally Determined Contribution ( INDC ). 2015. 
[105] Republic of the Philippines. REPUBLIC OF THE PHILIPPINES Intended Nationally Determined Contributions 2015:1-6.

[106] Malekpoor H, Chalvatzis K, Mishra N, Dubey R, Zafeirakis D. Integrated Grey Relational Analysis and Multi Objective Grey Linear Programming for Sustainable Electricity Generation Planning. Ann Oper Res 2017.

[107] Rutter R, Chalvatzis KJ, Roper S, Lettice F. Branding Instead of Product Innovation: A Study on the Brand Personalities of the UK's Electricity Market. Eur Manag Rev n.d.:n/a--n/a. doi:10.1111/emre.12155. 